want to look as if it hasn't lived up to a promise it made to invest ten percent of its revenue in Canadian research. Erola's job is to make sure things look favorable for the industry. However, she denies having to lean on PMAC companies to get them further involved in MRCassociated funding. "There had never been an agreement like that before and it was slow to get started. It took minor tweaking to get going."

Erola is not the only one confident the industry will more than live up to its commitments. " $\mathrm{I}$ ' $\mathrm{m}$ convinced there is a much stronger commitment on the part of companies," said Howard Dickson, who heads up medical research at Dalhousie University in Halifax, Nova Scotia. "Twenty years ago, if I had stable funding from the MRC, that's all I needed," he said. But that is no longer true. "It's a reality. You've got to diversify and look at alternatives."

In addition to being a realist, Dickson is also concerned about the infrastructure at Canadian universities and their ability to train the next generation of researchers. Much of the vaunted MRC/PMAC fund is slated to go to hiring and teaching the next generation of researchers although little, so far, has been allocated.

\section{JOE MCAlLister}

Toronto, Canada

\title{
Australian doctors protest limits
}

The Australian government's new law aimed at limiting the number of doctors who can work under the national healthcare system, which came into effect on 1 November, sparked widespread industrial action by junior doctors throughout the country. In South Australia and Western Australia, only emergency medical services were available, while in Queensland, Victoria and New South Wales, medical staffs went on "symbolic strike," working in T-shirts bearing "Doctors on Strike" in large red letters.

The striking doctors were angered by the new regulations that require all future general practitioners to undertake additional years of study in order to be issued a Medicare provider number, the registration required to get government reimbursement for services rendered in private practice. Without this "license," doctors can only work in public hospitals or do administrative and other work.

Under the previous system, students went through 6 years of training, followed by 1 year residency, after which they were issued a provider number. Specialists went on to a further 5-6 years of study, at the end of which they could either con-

\section{Foreign-trained physicians locked out}

In a bid to limit the number of doctors working in Australia, the Federal government has introduced a ten-year moratorium on allowing foreign trained doctors to work in private practice under Medicare, the national health care scheme.

The initiative, which comes into effect on 1 January 1997, was announced in late October, a few days before new legislation aimed at limiting the number of general practitioners came into effect on 1 November (story this page). It applies to all foreign trained doctors, including Australian citizens, according to a spokesman for the Australian Medical Association.

Federal health minister Michael Wooldridge justified the move by stating that Australia's medical migration has been out of control for nearly a decade. His department figures reveal that 600 medically trained people move to Australia each year, mostly under family reunification rules, 200 of whom eventually pass the Australian Medical Council's examination. (The latest available figures show there are now 230 doctors per 100,000 population).

Under the new law, doctors entering the country will still be able to sit for the examination, but they will have to wait 10 years before they can be issued a Medicare provider number - their ticket to private practice. In the meantime, they will be allowed to work in public hospitals.

The health department says the measure will ensure that Australia does not become the last country in the Western world to allow unrestricted migration of doctors. It is also aimed at alleviating the fear of Australian medical students that they will have to compete with foreign trained doctors for postgraduate training places. They need to obtain their own Medicare registration number, as specified in the new regulations introduced on 1 November.

ELIZABETH BAN Sydney, Australia

tinue with their speciality or become GPs. But after 1 November, all doctors have to undergo a further 4- to 5-year postgraduate training before being issued a provider number. The goal of the legislation is to accommodate the government's stated intention in its first budget, to limit to 1000 the number of Medicare provider numbers it issues each year (Australian universities graduate 1200 students a year, half of whom go into general practice after graduation.)

The government says the move was made necessary by an oversupply of doctors in this country, with each extra doctor costing the government an estimated A $\$ 136,500$ a year in reimbursements. The new legislation is expected to net savings of $\$ 20.2$ million this year alone, with increasing annual savings reaching $\$ 200$ by fiscal year $1999-2000$.

The Australian Institute of Health and Welfare estimates there are 4,500 too many GPs in urban areas, but practicing inner city doctors who have difficulty attracting locums for night work and vacation relief disIMAGE pute this claim. However, NNAVAILABLE according to a spokesman of the Australian Medical Asso-

FOR COPYRIGHT ciation (AMA), the oversupply is real and the problem is instead one of distribution, shich the government will have to address. The AMA is in a difficult position; it agrees क्ष restricted, but as the doctors' representative it has to bargain on their behalf.

Student activists fear that 1000 of them now in training will not be able to practice under the new regulations, because there are simply not enough postgraduate training positions. They are also angry that the government has introduced the new system without making transitional arrangements.

Health minister Michael Wooldridge says the new system is nonnegotiable, and that it will lead to fewer, but better trained, doctors. The AMA agrees with the government and other analysts that the root cause of Australia's burgeoning health-care costs is unlimited access, but says that limiting the number of doctors without increasing patient copayment is not the way to solve the problem.

ELIZABETH BAN Sydney, Australia 